\title{
MEDICAL CARE FOR DEPENDENT CHILDREN: MANSLAUGHTER LIABIIITY OF THE CHRISTIAN SCIENTIST
}

\author{
Robert L. Trescher $\dagger$ \\ AND \\ Thomas N. O'Nent, JR.
}

Manslaughter is one of the few crimes the commission or noncommission of which may be dependent upon the actor's motivating beliefs. Where those beliefs are regarded as reasonable, conduct arising from them which would otherwise amount to manslaughter may be regarded as noncriminal. The criminal law's concern over belief, or motive, in this area is striking when compared to the usual criminal situation-armed robbery, for example, is criminal despite the fact that the actor may feature himself a modern-day Robin Hood. ${ }^{1}$

What factors bear on the question of reasonableness of a belief? Certainly public acceptance is important; as a belief becomes widespread and held by a substantial segment of society, it becomes easier to accept that belief as reasonable. But judicial and legislative recognition of a belief as a permissible one also plays a part-and on occasion a crucial one. For example, judicial and legislative recognition of a belief, action upon which has resulted in the death of another, may influence the course of a prosecution for that death through the exercise of the prosecutor's discretion. The prosecutor may decide that the prosecution is contrary to a public policy enunciated in legislative acts and court decisions, or that it smacks of unfairness because those statutes and decisions indicated to the actor that his belief was reasonable and that action upon it would be noncriminal. Or it may influence a jury-a belief which has apparent legislative and

$\uparrow$ B.S. 1934, LI.B. 1937, University of Pennsylvania. Member, Philadelphia Bar.

A.B. 1950, Catholic University of America; LL.B. 1953, University of Pennsylvania. Member, Philadelphia Bar.

1 Two familiar law school cases may serve to illustrate these introductory remarks. In the first, Rex v. Esop, 7 Car. \& P. 456, 173 Eng. Rep. 203 (1836), a foreign sailor whose vessel had docked at an English port committed sodomy while aboard the ship; the court stated that the defendant could be convicted of that offense despite his belief, based on the laws of his native land, that such conduct was not criminal. Here the erroneous belief concerned the substance of the law; seldom in such cases does our legal system concern itself with belief. The second case, Rex v. Machekequonabe, 28 Ont. 309 (Can. Div. Ct. 1897), resulted in a conviction of manslaughter where an Indian, believing a shadowy figure to be an evil spirit, shot at the "spirit" and killed his father-in-law. Here the erroneous belief was a factual one and it.is at this point that the law concerns itself with the reasonableness of the belief. 
judicial sanction is difficult to regard as unreasonable. And eventually previous judicial and legislative acceptance of a belief may be reflected in the criminal laws themselves-either through judicial decision based on considerations of legal consistency or through explicit legislative act.

The gradual judicial, legislative, and social acceptance of a belief has been illustrated in the development and spread of Christian Science and other less well known forms of spiritual healing. But a remaining question-and one especially important to those who practice spiritual healing-is whether belief in the healing effects of prayer has been so far accepted that a death resulting from failure to secure medical aid because of that religious conviction does not constitute involuntary manslaughter.

The question of whether religious belief is a defense to a manslaughter prosecution based on failure to provide medical attention for a dependent child recently has been raised again after a lapse of several decades. $^{2}$ In $1956 \mathrm{Mr}$. and Mrs. Edward Cornelius were indicted for involuntary manslaughter in Pennsylvania ${ }^{3}$ following the death of their infant son from diabetes. Both parents were Christian Scientists ${ }^{4}$ and, interpreting the teachings of the Bible ${ }^{5}$ as conferring the power and duty to rely solely on spiritual means for healing, believed that healing takes place by the action and power of God and that all sickness, however serious, can be healed by spiritual means alone. ${ }^{6}$

The case affected the legal right of all Pennsylvania members of the Christian Science Church, a substantial and well-established faith, ${ }^{7}$

2 Research yields no case concerning failure to supply medical aid as a result of medical beliefs since Commonwealth v. Breth, $44 \mathrm{~Pa}$. County Ct. 56 (1915). See the discussion of this case at notes 53-54 infra and accompanying text. Since the Cornelinis indictment, one somewhat similar case has arisen in Maryland. See notes 43-48 infra and accompanying text.

3 Involuntary manslaughter, a common-law crime in Pennsylvania, is defined as follows: "Involuntary manslaughter consists in the killing of another without malice and unintentionally, but in doing some unlawful act not amounting to a felony nor naturally tending to cause death or great bodily harm, or in negligently doing some act lawful in itself, or by the negligent omission to perform a legal duty." "Commonwealth v. Root, $191 \mathrm{~Pa}$. Super. 238, 242, 156 A.2d 895, 898-99 (1959). The Cornelins indictment was based on an alleged failure to perform a legal duty.

4 At the time of the indictment Mr. and Mrs. Cornelius were 37 and 33 years of age respectively. Both had been taught to rely on Christian Science since their earliest recollections and both were active members of First Church of Christ, Scientist, Swarthmore, $\mathrm{Pa}$., and also of The Mother Church, The First Church of Christ, Scientist, in Boston.

5 These teachings include the command of Christ, as related in Matt. 10:8, to "Heal the sick, cleanse the lepers, raise the dead, cast out devils . . . ."

6 The Cormelius case presented no issue as to the sincerity of the defendants' religious convictions. The defendants used the help of a Christian Science practitioner and, when their son failed to respond as they had hoped, placed him in a Christian Science nursing home in Philadelphia. There was no question that everything the defendants did in connection with their son's illness was in good faith, carefully considered, and based on deep religious convictions.

7 The Mother Church and the main offices of the Church are in Boston. There are about 3,200 Christian Science churches throughout the world, of which 2,412 are 
to apply the tenets of their religion in ministering to the ills of their minor children. Aside from its legal significance to this group, it was attended by extensive publicity because of its emotional impact upon the public. It brought into sharp focus the question whether there has been such acceptance in Pennsylvania law of healing by spiritual means alone that it is a permissible healing art on which parents are entitled to rely.

\section{Eardy English Cases}

\section{At Common Law}

At common law there was a division of authority on the question of whether a religious belief was a defense in a prosecution for manslaughter based upon failure to provide medical attention for a dependent child. No English court was faced with this question until the last half of the nineteenth century, when a series of indictments was entered against members of a religious sect calling themselves the "Peculiar People." One of the tenets of this religion was reliance on Providence in cases of illness rather than summoning medical help.

The first case involving the Peculiar People, Regina v. Wagstaffe, ${ }^{8}$ arose in 1868 . The court, in charging the jury, distinguished between the denial of food based on religious belief and a denial of medical treatment for similar reasons. It said that in the former case a jury could "stamp the conduct with the imputation of gross and culpable negligence" ${ }^{9}$ because the belief might be so absurd that it could not have been honestly obtained, in which event the pretense of acting for the best would be removed from the case. ${ }^{10}$ With regard to medical treatment, however, the court stated that it was an open question as to whether the defendants were guilty of culpable negligence: "At different times people had come to different conclusions as

in the United States and 83 in Pennsylvania. Each church conducts Sunday School, regular Sunday services, and also Wednesday night meetings at which testimonials of healings are recounted. The church, through one of its agencies, publishes a widely circulated daily newspaper, the Christian Science Monitor. It also sponsors a Sunday morning television broadcast, and a radio broadcast in which actual verified accounts of healings are given by persons who have experienced them. Throughout the country Christian Science churches maintain thousands of reading rooms for the benefit of the public and the circulation of Christian Science literature, including monthly and weekly periodicals containing verified testimonies of healings through Christian Science. Throughout the world, there are approximately 10,000 Christian Science practitioners whose function is to assist in healing by spiritual means alone. In addition, there are fifteen Christian Science nursing homes in the United States, including the one in Philadelphia to which the Cornelius child was sent for care.

810 Cox Crim. Cas. 530 (1868).

I Id. at 533 .

10 Compare Commonwealth v. Pierce, 138 Mass. 165 (1884), where the defendant, holding himself out as a physician, was convicted of manslaughter when his patient died after being bound in kerosene-soaked flannel as the defendant had prescribed. 
to what might be done with a sick person." 11 A verdict of not guilty was returned. The report of the Wagstaffe case consists solely of the vaguely worded charge which, in effect, left to the jury a determination of whether the religious belief held by the defendants was reasonable. It should be noted, however, that later writers have accepted $W$ agstaffe as the authoritative statement of the common-law rule. ${ }^{12}$

Two other cases ${ }^{13}$ were decided after the passage of the Poor Law Amendment Act of $1868,{ }^{14}$ but reference to the new statute was omitted and common-law principles apparently were applied. No written opinion is reported in the first case, Regina $v$. Hurry, ${ }^{15}$ except for the fact that the defendant was convicted of unlawfully neglecting to provide medical aid to his child. ${ }^{16}$ In the other case a member of the Peculiar People was indicted for "unlawfully endangering the life of his child" who had died of pneumonia. The trial judge, in directing a verdict of acquittal, spoke in terms of there being "no culpable omission of duty" where a parent has dealt with his child "by nursing and care instead of calling in a doctor to apply blisters, leeches and calomel ...."17

\section{Under Statutes Protecting Dependent Children}

Few other English judges were given an opportunity to rule on the religious belief problem under common law. Within six months

1110 Cox Crim. Cas. at 533.

12 The American and English Encyclopedia of Lawe, for example, cites the case as its sole authority for the following statement: "Under the common law no conviction of manslaughter predicated upon an omission to provide medical attendance from conscientious motives has been reported, and none can probably be had or sustained. Opinions have widely differed in all ages as to the proper mode of ministering to the sick, and in the absence of a statute declaring it a positive duty upon a parent to call in a medical practitioner the omission to do so can scarcely be considered negligence so gross and wanton as to be criminal when the fact is admitted that the defendant acted in all good faith, doing the best he could according to his lights." 21 AMERICAN AND ENGLISH ENCYCLOPEDIA OF LAW 199 (2d ed. 1902). And in 1 Wharton, Criminal Law $\$ 462$ (12th ed. 1932), this statement appears: "Where from a conscientious conviction that God would heal the sick, and not from any intention to avoid the performance of their duty, the parents of a sick child refuse to call in medical assistance, though well able to do so, and the child consequently died, this was held at common law not to be culpable homicide." In addition to Wagstaffe, Wharton cites Regina v. Hines, 80 Cent. Crim. Ct. 309 (1874).

13 Regina v. Hines, supra note 12; Regina v. Hurry, 76 Cent. Crim. Ct. 63 (1872).

$1431 \& 32$ Vict. c. 122, \$37. See the discussion of this statute at notes 18-21 infra and accompanying text.

1576 Cent. Crim. Ct. 63 (1872).

16 That the indictment was framed in terms of unlawfully neglecting to provide medical aid may indicate that the case was tried under the Poor Law Amendment Act, rather than under purely common-law principles. However, no specific mention of the statute is made in the report of the case. Additional support for the view that the case was tried under common-law principles is found in the prosecutor's statement in Regina v. Downes, L.R. 1 Q.B. 25, 29 (1875): "The authorities are not in harmony as to whether this conviction could be sustained at Common Law. The ruling of Byles, J., in Reg. v. Hurry is clearly in favour of it, while those of Willes, J., in Reg. v. Wagstaffe, and Piggott, B., in Reg. v. Hines, tend the other way."

17 Regina v. Hines, 80 Cent. Crim. Ct. 309, 312 (1874). 
after the Wagstaffe case, and obviously as a result of that decision, Parliament added the words "medical aid" to the Poor Law Amendment Act of $1868 .^{18}$ After this amendment, the act provided that "when any Parent shall willfully neglect to provide adequate Food, Clothing, Medical Aid, or Lodging for his child . . . whereby the Health of such Child shall have been . . . injured, he shall be guilty of an Offense...."

In Regina v. Downes, ${ }^{19}$ it was held that the new statute subjected parents to criminal liability for failure to provide medical treatment regardless of the fact that the failure was based on religious belief. This holding has been unchallenged in subsequent cases arising under the 1868 statute and under its more recent and more pervasive counterpart, the Children and Young Persons Act of 1933. ${ }^{20}$ Two of the judges in Downes, however, doubted that the conviction could have been sustained without the aid of the statute. ${ }^{21}$

In 1894 the Poor Law Amendment Act was repealed by the Prevention of Cruelty to Children Act, ${ }^{22}$ which provided merely that anyone who had in his custody or care a child under the age of sixteen years and who wilfully neglected such child in a manner which was likely to cause it unnecessary suffering or injury was guilty of a misdemeanor. The change in wording, however, had little effect on the results of subsequent cases tried under the statute.

In the first reported case ${ }^{23}$ under the Prevention of Cruelty to Children Act, the jury was told that it must find the defendants guilty if it believed that the absence of medical treatment accelerated the death of their child. The judge charged that it did not matter that the defendants had thought they were doing right and warned the jury not to be carried away by any sympathies for conscientious objections.

A more significant case which arose under the act is Queen $v$. Senior. ${ }^{24}$ There, the trial judge charged both in terms of common-law gross and wanton negligence ${ }^{25}$ and also under the misdemeanor-man-

$1831 \& 32$ Vict. c. $122, \S 37$.

19 L.R. 1 Q.B. 25 (1875).

2023 Geo. 5 , c. $12, \S 1$ (2) (a).

21 Lord Coleridge, who delivered the prevailing opinion, had this to say of the common-law rule: "[H]ad it not been for the statute.. . I should have entertained great doubt upon this case; for, apart from the argument founded upon the statute, I think the observations in the cases cited before Willes, J., [Wagstaffe] and Piggott, B., [Hines] are deserving of the greatest consideration." L.R. 1 Q.B. at 29. And in concurring, Bramwell, B., said: "I agree with my Lord Coleridge as to the difficulty which would have existed had it not been for the statute." L.R. 1 Q.B. at 30.

$2257 \& 58$ Vict. c. 41.

23 Regina v. Cook, 62 J.P. 712 (1898).

24 [1899] 1 Q.B. 283.

25 See $i d$. at 285 : "In order to make out a case of manslaughter by negligence in a case of this kind purely at common law, the negligence must be gross and wanton, 
slaughter rule. ${ }^{26}$ The defendant was convicted and the conviction was upheld by the Court of Appeals, with the trial judge in Wagstaffe, then sitting on the appellate court, concurring in the result. ${ }^{27}$

The numerically meager and substantively divided English cases provide no clear answer as to whether religious belief was a defense to manslaughter prosecutions grounded on a failure to provide medical care. The majority of purely common-law cases supports the view that conscientiously held belief was a defense; but where some statute imposed an affirmative duty to provide medical aid to dependent children, or merely made criminal the neglect of such persons, the English courts had little trouble striking down a defense based on religious convictions.

\section{AMERICAN JuRISDictions}

\section{The Early Cases}

In American jurisdictions, cases involving religious belief as a defense to a criminal prosecution for failure to provide medical assistance to minors also have been scarce. The first significant prosecutions in which a defense of religious conviction was raised were brought shortly after the turn of the present century. In State $v$. Sandford, ${ }^{28}$ the leader of a religious community which believed in and practiced faith healing was convicted of manslaughter as a result of the death of a member of that community. $\mathrm{He}$ was charged with failing to provide medical care and food, the latter apparently as a result of a religious fast. The trial court charged the jury that an omission to provide medical care as a result of a belief in faith healing did not provide the basis for a conviction of manslaughter, but that criminal negligence existed if the defendant failed to act according to his beliefs in the efficacy of prayerful healing and such failure hastened death. The conviction was reversed on the grounds that the last portion of the charge made the causation problem dependent on the beliefs of the

so much as to indicate something, at all events, of an evil mind, and that it was impossible to say that of the prisoner, who was shown to have spared neither expense nor care, and to have taken, in all respects but one, every precaution to do the best for the child."

26 The trial judge stated that if the defendant had done something expressly forbidden by statute and by so doing had caused or accelerated the child's death, he would be guilty of manslaughter. See [1899] 1 Q.B. at 285.

27 This concurrence is especially interesting inasmuch as the opinion contained the following dictum: "I wish to add that I dissent entirely from the view attributed to Piggott, B., in Reg. v. Hines (1), and I am not satisfied that in the present case there was not sufficient evidence, at common law, to justify a conviction." [1899] 1 Q.B. at 292. The Hines case reached a result similar to that in Wagstaffe.

2899 Me. 441, 59 Atl. 597 (1905). 
jury as to the healing effects of prayer. ${ }^{29}$ The court approved the former portion of the charge accepting reliance on faith healing as a defense.

In State v. Chenowith, ${ }^{30}$ the defendant was charged with manslaughter following the death of his infant son from bronchopneumonia. The father had called in an "elder" and had resorted to prayer for the treatment of his son. Though acquitting the defendant on procedural grounds, the court said in dictum that religious beliefs constitute no defense to a manslaughter prosecution predicated on the failure of a parent to give medical assistance to his child, ${ }^{31}$ and the case has been cited for that proposition. ${ }^{32}$

At about the same time as Sandford and Chenowith, two casesPeople v. Pierson ${ }^{33}$ and Owens v. State ${ }^{34}$-arose in New York and Oklahoma respectively, under statutes similar to the Poor Law Amendment Act of $1868 .^{35}$ Both statutes made it a misdemeanor wilfully to omit to furnish medical attendance to a minor. ${ }^{36}$ In both cases the defense of religious belief in faith healing was raised and rejected, the courts stating that religious convictions are not a defense to a duty imposed by law. While the statute involved in the Oklahoma case remains the same today, ${ }^{37}$ the New York statute has been amended significantly to provide that "this article shall not be construed to deny the right of a parent . . . to treat . . . an ill minor in accordance with the religious tenets of any church as authorized by other statutes of this state, provided: That the laws, rules, and regulations relating to communicable diseases and sanitary matters are not violated." 38

28 The distinction between allowing the beliefs of the jury to be determinative of the causation issue and allowing those beliefs to determine whether the defendant's religious conviction was reasonable should be noted. To allow the jury to pass on causation under the charge in question would have required a decision as to the efficacy of healing by prayer; in fact, under the charge as given, no conviction could have been had unless the jury believed that faith healing was efficacious. On the other hand, to present the jury with the issue of whether the defendant's belief was reasonable requires no such decision on the soundness of faith healing. Here, the court apparently decided the reasonableness issue as a matter of law and then proceeded to give its unusual instructions on the issue of causation.

30163 Ind. 94, 71 N.E. 197 (1904).

31 Id. at 99,71 N.E. at 199.

32 See Prince v. Massachusetts, 321 U.S. 158, 166-67 n.13 (1944).

33176 N.Y. 201, 68 N.E. 243 (1903).

346 Okla. Crim. 110, 116 Pac. 345 (1911).

35 See notes 14, 18-21 supra and accompanying text.

36 N.Y. Pen. Laws §482; Orla. Stat. Ann. tit. 21, §852 (1951).

37 A case similar to Ozens arose in 1925 under the Oklahoma statute but a defense predicated on religious beliefs was not raised, presumably because of the previous ruling in Owens. The court specifically noted its adherence to the prior case. Beck v. State, 29 Okla. Crim. 240, 233 Pac. 495 (1925).

38 N.Y. PEN. LAws $\$ 495$. Cf. the pertinent New Jersey statute, which reads: "The provisions of this act shall not be construed to deny treatment by spiritual means or prayer, of any child, in accordance with the religious faith of the parent 
In 1902 the Georgia Supreme Court ruled that a statute of that state which made it a misdemeanor to deprive a child of "necessary sustenance" could not provide the basis for a prosecution for failure to provide medicine, medicine not being included within the definition of "sustenance." 39 The defendant father claimed that his religious beliefs forbade him from providing medication but the court did not pass on the validity of this defense.

In 1920 a Florida court ruled that the statutory definition of manslaughter did not encompass a death resulting from a failure to provide medical attention. ${ }^{40}$ The defendant was the father of an epileptic child who, while seized with a paroxysm, had fallen into a fire and suffered severe burns. As a result of his religious beliefs the father did not treat the burns with medication. In contrast, a Tennessee court the previous year had overruled the quashing of an indictment predicated on a father's omission to provide medical attention for his child. ${ }^{41}$ The Tennessee court cited Queen $v$. Senior ${ }^{42}$ with approval although there was no mention of a defense based on religious convictions.

\section{Craig v. State}

In 1959 the religious belief issue again was raised, this time before the Court of Appeals of Maryland in Craig v. State. ${ }^{43}$ The defendants were indicted and convicted of involuntary manslaughter following the death of their six-months-old daughter from pneumonia. Being members of the Church of God, ${ }^{44}$ the parents did not utilize medical assistance but did treat their daughter in accordance with the tenets of their faith. On appeal, the court, though concluding that a specific statutory duty to provide medical care existed, ${ }^{45}$ reversed the

or parents of such child. The provisions of this act shall not be construed to authorize or empower the State Board of Child Welfare to compel a child to undergo medical or surgical treatment, if the child, or parent or guardian of said child, objects thereto in a signed statement upon the ground that the proposed action interferes with the free exercise of his religious principles." N.J. Rev. STAT. \& 30:4C-6(a) (Supp. 1959).

39 Justice v. State, $116 \mathrm{Ga} .605,42$ S.E. 1013 (1902).

40 Bradley v. State, 79 Fla. 651,84 So. 677 (1920). The court alternatively held that there was no showing that the defendant's omission was the proximate cause of the child's death.

41 State v. Barnes, 141 Tenn. 469, 212 S.W. 100 (1919).

42 [1899] 1 Q.B. 283. See notes 24-27 supra and accompanying text.

43220 Md. 590, 155 A.2d 684 (1959).

44 The religion of the defendants is not made clear in the reported decision; however, independent investigation of the facts of the case indicates that the defendants were not Christian Scientists and that the treatment used was not Christian Science treatment. In the advanced stages of the infant's illness, an attempt was made to utilize Christian Science practitioners.

45 The court reached this conclusion on the basis of a Maryland statute which charges parents with the duty of "support, care, nurture, welfare and education" of their minor children. See MD. ANn. Cone art. 72A, \&1 (1957). 
conviction and remanded for retrial on the issue of proximate cause. The court stated that if the parents showed a wanton and reckless disregard for the child's life by omitting medical care during that period of the illness when medical assistance, if given, would have been effective to prevent death, the omission would constitute the proximate cause of death. That religious convictions were the basis for the omission of medical care, the court said, is "beside the point." 46

In remanding the Craig case, the Maryland court considered and rejected claims of constitutional protection derived from freedom of religion, due process of law, and equal protection of the laws. In discussing the claim of freedom of religion, the court stated that the freedom to believe is separate from the freedom to act and that action is subject to regulation in the interests of the health and welfare of the community. ${ }^{47}$ In the case of a Christian Scientist, however, an integral part of his creed is belief in healing by spiritual means. Thus, to deny to a Christian Scientist the right to act in accord with his religion is in effect to deny him his religion. This particularly interesting question of the boundaries of religious freedom under the first amendment and under the due process clause of the fourteenth amendment was not presented in these terms in Craig, which, as has been noted, did not involve Christian Scientists.

The court also rejected the claim that the Maryland statute requiring that medical treatment be given to minors was vague and indefinite as applied to defendants. And, finally, the argument was made and rejected that a statute which exempts Christian Science practitioners ${ }^{48}$ from the requirement of obtaining a medical practice license allowed Christian Scientists to pursue their faith but denied that right to defendants, thus violating the constitutional guarantee of equal protection of the laws. The court stated that the statute in question merely permitted Christian Science practitioners to give treatment but did not make such treatment the legal equivalent of medical care.

The only conclusion which can be reached from a consideration of cases arising in American jurisdictions is that the problem has been little considered and no single doctrine has been established. Different

$46220 \mathrm{Md}$. at $598,155 \mathrm{~A} .2 \mathrm{~d}$ at 689.

47 In its elaboration of this point, the court relied principally on Reynolds $v$. United States, 98 U.S. 145, 161-67 (1878), and People v. Pierson, 176 N.Y. 201, 68 N.E. 243 (1903). In Reynolds, the beliefs of the Mormon church were advanced as $a$ defense to a bigamy prosecution. The court emphasized that bigamy had always been considered odious and illegal in Western Europe and that it was impossible to believe that the first amendment was intended to prohibit legislation outlawing polygamy. But the court's reliance on Reynolds may be questioned inasmuch as there has been no similar history with respect to belief in divine assistance for healing. And the court's second authority, Pierson, has been, in effect, overruled by statutory amendment. See note 38 supra and accompanying text.

48 See Md. ANn. Code art. 43, §140 (1957). 
states have reached opposite conclusions, as in the Sandford and Chenowith cases. However, as was the case in England, where a statute is held to impose a specific duty to provide medical care there has been no difficulty in overruling a defense predicated on religious beliefs. ${ }^{49}$

\section{Pennsylvania: A Case Study in Public Acceptance}

The state of Pennsylvania provides an enlightening example of how gradual public acceptance of a belief is reflected in the criminal law. After two early cases in which a defense of religious belief was rejected and parents were held liable criminally for failure to provide medical care, ${ }^{50}$ judicial and legislative acceptance of faith healing, and more specifically of Christian Science, has so increased that such prosecutions probably could not be sustained today against Christian Scientists.

Pennsylvania has no statute imposing a specific duty upon parents to provide medical care, such as was involved in People v. Pierson, or even a less precisely worded act similar to that in Craig v. State. One provision of the penal code provides that it is a misdemeanor for a parent wilfully to omit to furnish "necessary and proper food, clothing or shelter" for a child, ${ }^{51}$ and another section makes it a misdemeanor for a husband or father wilfully to neglect "to maintain his wife or children." 52 In 1915 the latter act was interpreted in Commonwealth v. Breth ${ }^{53}$ as requiring medical attendance for ill dependent children. ${ }^{54}$ And one earlier Pennsylvania case, Commonzealth v. Hoffman, ${ }^{55}$ seemed to reach the same result at common law as Regina $v$. Hurry in England and State v. Chenowith in Indiana. Both Pennsylvania cases

49 See Beck v. State, 29 Okla. Crim. 240, 233 Pac. 495 (1925) ; cf. Mitchell v. Davis, 205 S.W.2d 812 (Tex. Civ. App. 1947).

50 Commonwealth v. Breth, $44 \mathrm{~Pa}$. County Ct. 56 (1915) ; Commonwealth v. Hoffman, $29 \mathrm{~Pa}$. County Ct. 65 (1903).

51 PA. STAT. ANN. tit. 18, \$ 4727 (1945).

52 Pa. Stat. AnN. tit. 18, \$4731 (Supp. 1959).

$5344 \mathrm{~Pa}$. County Ct. 56 (1915).

54 Subsequent legislative treatment and judicial construction of this provision indicate that the Breth interpretation probably was erroneous. In the 1939 consolidation and revision of the criminal laws, the section was included with two others entitled "Neglect to Maintain Bastard" and "Desertion and Nonsupport"; the tone of all three sections speaks to the physical desertion of dependents by a husband or father. And in 1942 the superior court, construing the provision in question together with $\mathrm{PA}_{\mathrm{A}}$. Stat. ANn. tit. 18, \&4733 (Supp. 1959) (desertion and nonsupport), stated that the latter provides for a support order while the former provides punishment for a deserting husband. See Commonwealth v. Widmeyer, 149 Pa. Super. 91, 26 A.2d 125 (1942). Thus, the provisions being mutually limiting, it would seem that the provision under discussion is directed only to the physical desertion and monetary nonsupport by a father rather than to the conscientious refusal of parents to provide medical aid.

$5529 \mathrm{~Pa}$. County $\mathrm{Ct}$. 65 (1903). The case was decided six months after the passage of the statute cited in Breth but the opinion made no mention of the provision. 
held that a father could be convicted of involuntary manslaughter for the death of his son where he did not secure medical treatment but preferred to rely on a form of spiritual healing alone. ${ }^{58}$

In the Hoffman and Breth cases, the courts based their decisions upon what they conceived to be the public policy of the commonwealth at that time and relied principally on two expressions of that policy. First, both courts relied on an earlier civil case in which a Christian Science church had been denied a charter on the ground that healing by spiritual means alone was opposed to the general policy of the law of Pennsylvania relating to the existence and treatment of disease. ${ }^{57}$ Second, the courts stressed the fact that, as of that time, only qualified physicians and surgeons were permitted to engage in the practice of healing. ${ }^{58}$

Between 1915 and 1956, when the Cornelins indictment was returned, no cases involving the question of religious belief in spiritual means of healing arose in Pennsylvania. Meanwhile, judicial decisions were handed down granting charters to Christian Science churches, sanatoriums, and nursing services; and statutes were passed indicating legislative approval of spiritual means of healing. The question provoked by Cornelius, then, was whether this judicial and legislative acceptance of Christian Science had so progressed as to change the public policy of Pennsylvania and destroy the basis of the Hoffman and Breth decisions.

The Non-Profit Corporation Law of Pennsylvania provides that a nonprofit corporation may be founded under the provisions of the act "for any purpose or purposes which are lawful and not injurious to the community." 59 There are eighty-three Christian Science churches in Pennsylvania, most of which have nonprofit corporation charters based on judicial decrees that their form of worship is lawful and not injurious to the community ${ }^{60}$ More important, both the sanatorium in

56 Neither case involved a Christian Scientist. The headnote of the Hoffman case states that the defendant "called in the elders of a Christian Scientist Church, who prayed over the child and anointed it with oil ...." However, the text of the case does not suggest that the defendant was a Christian Scientist and the treatment described is not Christian Science treatment.

57 First Church of Christ, Scientist, $205 \mathrm{~Pa} .543$ (1903). See also Application of First Church of Christ, Scientist, $6 \mathrm{~Pa}$. Dist. 745 (C.P. 1897).

58 In addition, the illness involved in Hoffman was scarlet fever and the court there dwelt on the contagious nature of the disease.

59 PA. Stat. Ann. tit. 15, §2851-201 (1958).

60 The church of which the defendants were members had received such a charter under the Non-Profit Corporation Law. See First Church of Christ, Scientist, Swarthmore, Petition for Charter, No. 140, March Term, 1924, Delaware County (Pa.) C.P., April 11, 1924. The articles of incorporation declared that: "Said corporation is formed for the support of public worship of God in accordance with the tenets of the Christian Science faith and the Manual of The Mother Church, The First Church of Christ, Scientist, in Boston, Massachusetts." 
which the Cornelius child was placed ${ }^{61}$ and an organization known as the Philadelphia Nursing Service for Christian Scientists ${ }^{62}$ had received charters based on such decrees, indicating that not only the form of worship but also the precise form of healing treatment prescribed by Christian Science had been judicially declared "lawful and not injurious to the community." "63 These decrees are a natural concomitant of the broad principle of law that the right of conscience " is simply a right to worship the Supreme Being according to the dictates of the heart; to adopt any creed or hold any opinion whatever, or to support any religion; and to do, or forbear to do, any act for conscience sake, the doing or forbearing of which is not prejudicial to the public weal." " 64

61 See In the Matter of the Application for the Incorporation of "The Philadelphia Sanatorium, Inc.," No. 4336, Dec. Term 1947, Philadelphia County (Pa.) C.P. No. 4, April 12, 1948. The master's report pointed out that "the treatment patients will receive is the Christian Science treatment given by registered practitioners as listed in the Christian Science Journal, and by Christian Science nurses . . . . They must show their ability to give prayerful healing. Medical doctors will not be in attendance in the sanatorium, but there will be in attendance nurses who are trained to take care of those who are not able to take care of themselves . . . . Neither homeopath or allopath medical treatment will be given."

62 See In the Matter of the Incorporation of the "Philadelphia Nursing Service for Christian Scientists, Inc.," No. 5244, Dec. Term 1947, Philadelphia Co. (Pa.) C.P. No. 5, July 15, 1948.

63 How this judicial declaration that Christian Science healing practices are "lawful and not injurious to the community" squares with PA. STAT. ANN. tit. 11, $\$ \S 243,250,252$ (1939) (Juvenile Court Act), is a difficult problem. Section 243 defines a "neglected child," in part, as one whose parent "neglects or refuses to provide . . necessary medical or surgical care," and $\$ 250$ authorizes the court to make such orders as shall be necessary for the welfare of the child, including orders as to custody. Section 252 provides that "the court shall place a child, as far as possible, under the care, guidance and control of persons have [sic] the same religious belief as the parents of the child ... and shall, as far as possible, provide, in making orders of placement, that the care, guidance and control of the child shall be as nearly as possible that which should have been given by his or her parents ...." Should a child of Christian Science parents be "neglected" in other than medical matters, the statutory directive as to custody seems clear: $\$ 252$ would be controlling and the child should be placed with Christian Scientist parents. But should a child be "neglected" as to medical care, the court would be faced with the conflict between the $\$ 243$ definition and judicial orders declaring Christian Science healing practices "not injurious"; complicating the conflict would be the other legislative recognitions of Christian Science, discussed at notes 65-72 infra and accompanying text. A possible resolution of this conflict would reserve the transferral-of-custody remedy for cases in which the child presents a danger to the health of the community. Compare PA. Stat. ANN. tit. 35, \$521.12(e) (Supp. 1959) and discussion at text accompanying note 67 infra. Note also that the removal of a child from its parents -an affirmative act by the state for the welfare of both child and community-is a matter quite different from the punishment of Christian Scientist parents after their child's death-an essentially negative act as concerns the dead child and any danger which he had represented to the community during his illness.

64 Specht v. Commonwealth, $8 \mathrm{~Pa}$. 312, 322 (1848) ; compare PA. Const. art. I, \$ 3: "All men have a natural and indefeasible right to worship Almighty God according to the dictates of their own consciences; no man can of right be compelled to attend, erect or support any place of worship, or to maintain any ministry against his consent; no human authority can, in any case whatever, control or interfere with the rights of conscience and no preference shall ever be given by law to any religious establishment or modes of worship." 
The granting of charters to Christian Science churches, sanatoriums, and nursing services indicates judicial acceptance of the purposes of such institutions and, impliedly, the right of the individual to utilize such services, at least for himself. Not so clearly implied is public acceptance and approval of the right of a parent to choose spiritual means of healing for his child. A greater indication of the acceptance of such doctrines in the latter area is found in legislative action. At the time of the Cornelius indictment, the legislature had prescribed a program of required medical and dental examinations for school age children. ${ }^{65}$ The act further provided that recommendations as to medical, surgical, or dental care should be forwarded by the school authorities to the family physician or dentist and to the parent or guardian of the child, who was then obligated to notify the school of the action taken with respect to the recommendations. ${ }^{66}$ However, a specific exception was made to these comprehensive requirements where the parent objected to examinations or treatment on religious grounds, provided that the objection did not create a "present substantial menace" to the health of others. ${ }^{67}$

In the law governing adoption the Pennsylvania legislature has further indicated its approval and acceptance of spiritual means of healing. The adoption law prescribes the procedures and conditions for the adoption of children and provides that "whenever possible, the petitioners shall be of the same religious faith as the natural parents of the child to be adopted. No person shall be denied the benefits of this act because of a religious belief in the use of spiritual means or prayer for healing . . . " 68 The only reasonable implication of this language is that parents of an adopted child may practice spiritual means for healing their child. And if adoptive parents may employ spiritual means or prayer for the treatment of their adoptive child, it seems clear that natural parents have the same right.

The Disease Prevention and Control Law of 1955 authorizes the issuance of a marriage license without the medical examination and

65 Pa. Laws 1949, No. 14, §§ 1401-38.

86 The act also provided for public assistance for medical, dental, or surgical care which the parent was unable to supply.

$67 \mathrm{~Pa}$. Laws 1949, No. 30, §1408. "This . . . article shall not be construed to compel any person to submit to any medical or dental examination or treatment . . . when such person, or the parent, or guardian of any such person objects to such examination or treatment on religious grounds, or to permit any discrimination against such person on account of such objections: Provided, that exemption from medical or dental examination shall not be granted if the Secretary of Health finds that facts exist under which the exemption constitutes a present substantial menace to the health of other persons exposed to contact with the unexamined person." This provision was reenacted without significant change in 1957 when the legislature revised certain aspects of the school health examination program. See PA. StAT. ANN. tit. 24, $\S 141419$ (Supp. 1959).

68 PA. Stat. ANN. tit. 1, §1(d) (Supp. 1959). (Emphasis added.) 
laboratory tests normally required, if the examination and tests "are contrary to the tenets or practices of the religious creed of which the applicant is an adherent, and ... the public health and welfare will not be injuriously affected thereby." 69 Pursuant to a similar predecessor provision, Pennsylvania courts have waived the premarital examination for members of the Christian Science faith. ${ }^{70}$

Still further indications of the legislature's approval of spiritual means of healing as a healing art are found in the statutes governing the practice of medicine and the nursing profession. The Medical Practice Act, while defining "healing art" as "the science of diagnosis and treatment in any manner whatsoever of disease," ${ }^{71}$ specifically exempts healing by spiritual means from the regulations governing the licensed practice of medicine and surgery. ${ }^{72}$ Likewise, the Chiropractic Registration Act does not apply "to any person who, as an adherent of a well recognized religion which uses spiritual means of prayer for healing, practices the healing art in accordance with its teachings." 73 And the Professional Nursing Law specifies that it does not prohibit "care of the sick, with or without compensation or personal profit, when done in connection with the practice of the religious tenets of any church by adherents thereof." 74 Thus, under the least permissive reading of these statutes, healing by spiritual means is certainly recognized and not prohibited.

Not only the legislature but also various private groups have accepted Christian Science as a permissible means of healing. Numerous accident and health insurance companies in the United States, Canada, and other countries now recognize Christian Science care and treatment by paying the expenses incurred for the service afforded by Christian Science practitioners and nursing homes. Furthermore, money paid for the services of Christian Science practitioners and nursing care stands on an equal footing with medical expenses so far as deductibility under the federal income tax laws is concerned. ${ }^{75}$

As a result of the judicial, legislative, and public recognition and acceptance of Christian Science and its healing methods, it is unlikely

69 Pa. Stat. Ann. tit. 35, §521.12(e) (Supp. 1959).

70 In re Application of Dollie $\mathrm{L}$. Riggs and David $\mathrm{R}$. Jones for a License to Marry, Orphans' Court of Allegheny County, June 29, 1956; In re Application of Mildred Shields and Thomas Holmes, Orphans' Court of Allegheny County, M.L. 54416 Series Two.

71 Pa. Stat. Ann. tit. 63, §401(d) (1959). (Emphasis added.) Pa. Stat. ANN. tit. 63, \&401(c) (1959). Almost identical definitions of "healing art" and "medicine and surgery" are found in the Statutory Construction Act. See PA. STAT. ANN. tit. 46, §§601(49), (63) (1952).

73 Pa. Stat. AnN. tit. 63, §623 (1959).

74 Pa. Stat. AnN. tit. 63, $\$ 214(6)$ (1959).

$753 \mathrm{CCH} 1943$ Stand. Fed. Tax Rep. $\int 6175$. 
that a conviction could have been had in the Cornelius case and doubt was cast even upon the desirability of continuing the prosecution. These doubts evidently were persuasive in the mind of the prosecutor. Citing the "present day legislative acts" recognizing healing by spiritual means and noting that "the disease of diabetes did not subject the public to any danger," he moved to nolle prosequi the indictment. The court, also persuaded, granted the prosecutor's motion. ${ }^{\mathbf{7 6}}$

As a result of the disposition of the Cornelins case, the legality of a parent's exclusive reliance upon spiritual means for the healing of his child seems to be confirmed. Commonwealth v. Hoffman and Commonwealth $v$. Breth can no longer be said to represent the law of Pennsylvania. They are based on premises as to the public policy of the commonwealth which are no longer valid-if indeed they ever were. With the possible exception of cases involving contagious diseases, a parent's decision to forego medical remedies and to employ spiritual means of healing-where that decision is based on a sincere belief in a religious tenet of a denomination whose beliefs and practices have been determined both legislatively and judicially to be lawful and not injurious to the community-will no longer subject him to criminal penalty if the healing be unsuccessful.

76 Commonwealth v. Cornelius, No. 105, April Sessions, 1956, Philadelphia County (Pa.) Quar. Sess., Nov. 5, 1958. "[W] "[Wile a conviction of involuntary manslaughter may, under some circumstances be predicated upon death attributable to the failure to provide medical care, the character of the ailment, the good faith of the parent is of supreme importance. If the failure to provide medical care is the result of religious tenet or a sincere belief in the inefficacy of medical treatment there may be no criminal responsibility under the law." Verbal opinion of Reimel, $J$. 